\title{
САМОІДЕНТИФІКАЦІЯ ЧЕРЕЗ ІНШОГО: ЗБІРКА «ОСОТЕ!» МИРОСЛАВА ЛАЮКА ЯК ЕКОЛОГІЧНА МІСТЕРІЯ
}

У статті зосереджено увагу на поетииі збірки «Осоте!» Мирослава Лаюка. Опозииія природного / культурного осмислюється як підстава для ревізії культурних смислів і відношень, щуо на них базується культурний консенсус. Доведено, щз культурні сюжети М. Лаюк бачить $i$ впізнає в динаміці природних прочесів і явищ; точніше, над іншими способами бачення i відображення домінує саме культурна оптика. Мовою культурних сюжетів Лаюк переповідає (а радше втілює) нескінченно повторювану містерію кругообігу життя $i$ смерті. Акцентовано, що прийняття Іншого відбувається як екологічна містерія, щзо скасовує ієрархічні стосунки влади і підпорядкованості на користь паритетності цे діалогу. Відповідно, культурний текст може бути інтерпретований як матриия сприйняття чуттевої реальності.

Ключові слова: Мирослав Лаюк; опозиџія природне / культурне; своє / інше; екологічна містерія.

Друга збірка Мирослава Лаюка «Осоте!» засвідчила, що в українську літературу прийшов непересічний поет, чиї твори, як влучно висловився Василь Герасим'юк, призначені для «людей книги», не вичерпуються «на першій площині сприйняття» [2, 211]. Одразу впадає в око досить рідкісне для української поезії (за винятком хіба М. Бажана чи I. Калинця) концептуальне мислення збіркою, а не довірливе покладання на емоційні інсайти, які дозволяють утримати цілісність поетичного висловлювання в межах окремого вірша, але мало допомагають у вибудовуванні надсюжету, що тримається на містерійному розкритті смислу в повторюваних образах і ситуаціях. Поезія М. Лаюка - це ще й зриме засвоєння досвіду попередніх поколінь у формі живої традиції, проте зі щасливим уникненням відвертого учнівства: 3 усією очевидністю у візіях поета прозирають голоси Б.I. Антонича, О. Лишеги, В. Голобородька, Т. Мельничука, I. Калинця, В. Герасим'юка, але не як позасвідомо відтворені взірці, а як один із багатьох інтертекстуальних пластів.

Така характерна для Лаюка немонологічність, неодномірність поетичного висловлювання найвиразніше явлена саме на рівні збірки з їі поліфонічними інтермедіальними включеннями, рефренами і лейтмотивами, прописуванням ключових сюжетів і образів у динамічному й послідовному саморозгортанні. Інтермедіальне співіснування i зрівноваженість живописних i музичних асоціацій, представлених радше не як відтворення знаних сюжетів i згадування відомих імен, а як спроба мислити музичними й живописними матрицями, гармонійно включеними до єдиного культурного поля, викликають асоціації 3 Калинцевими «Звуками» i «Кольорами». Якщо 
говорити про збірку як цілісність, то послідовне драматичне розгортання того самого образу чи сюжету, але явленого щоразу в інших смислових координатах, асоціюється 3 містерією - містерією пізнання-упізнавання (ключовий образ дається як щоразу інша відповідь на те саме питання, актуалізуючи матричну для сюжету запитування сув’язь загадки і міфу [1, 123]) й містерією життя, смерті й відродження, лише опосередковано дотичною до християнського контексту. А от послідовне втілення основного сюжету в різних формах i вимірах, взаємодоповнюваність ключових концептів і смислових блоків нагадують високоорганізовану музичну форму фуги.

Як слушно зазначає Василь Герасим'юк у післямові до збірки, «Стати собою» - така назва книжки Мирослава Лаюка, тобто така моя версія прочитання його назви-символу» $[2,216]$. Я б уточнила - йдеться радше не про потребу статичної цілісності (ставання собою як збирання докупи фрагментованого світу і розірваного Я), а про динамічну зміну контекстів, невтомне промацування меж, виражене у філософському запитуванні: а чим Я не $\epsilon$ ? Це спостереження Герасим'юка вельми симптоматичне: ідентичність покоління вісімдесятників окреслювалась через процес розмежування радянського i національного, модерного i соцреалістичного, поетичного i риторично-публіцистичного, закоріненого і безгрунтовного, а для покоління навіть не двотисячників, а десятників ці межі цілком природно і сподівано виявилися завузькими. Адже йдеться вже не про відвоювання, а про розширення простору, в якому незагрожене Я може собі дозволити бути гармонійно співмірним із навколишнім світом. Наскільки Я - це Я, а Інший це Інший? Наскільки Я в своїх межах може бути Іншим для себе? Саме ці розмисли є смисло- і сюжетоорганізуючою віссю збірки «Осоте!».

Містерія пізнання-упізнавання в збірці Лаюка розігрується на кількох рівнях: родовому, культурному і природному. Книжність, впосадженість у культуру $є$ тією традицією, що ii в двадцятому столітті переймають неокласики, С. Плужник, ранній П. Тичина, яка тягнеться через творчість М. Рильського, М. Бажана, поетів празького й варшавського кола, Б.- І. Антонича, В. Стуса, І. Калинця, Київської школи, генерації вісімдесятників, дев'яностників - I. Андрусяка, Р. Мельникова, О. Галети - й органічно продовжується в поезії М. Лаюка. Родовий вимір самості, проблеми закоріненості, національної історії й пам'яті найповніше реалізуються в творчості Київської школи, вісімдесятників і С. Жадана, i М. Лаюк цю традицію продовжує і розглиблює. Вітальність живої матерії, міфологія лісу й осмислення людини як частини екосистеми, найочевидніше явлена в ліриці В. Свідзінського, Б.-І. Антонича, Київської школи, П. Мідянки, О. Лишеги, актуалізується також і в поезії М. Лаюка.

Проте молодий поет пропонує зовсім іншу концепцію співвідношення природного / культурного, звірино-рослинного / людського, родового / індивідуального. Культурні сюжети М. Лаюк бачить і впізнає в динаміці природних процесів і явищ; точніше, над іншими способами бачення i 
відображення домінує саме культурна оптика. Такий спосіб сприйняття й інтерпретації дійсності свідчить про те, що культурне поле представлене в цій ліриці не через інформаційний вимір - як сукупність відомостей, каталог імен і творів, множина величин, показник ерудованості, - а передусім як кут зору, матриця мислення, цілісний текст із певними сюжетними й образними домінантами. Якщо звернутися до перипетій людського світу, то цілком очевидно, що Інший поетові значно цікавіший за Я, причому сприймається він не через призму схожості / інакшості, а - парадоксальним чином - як продовження Я, буття Я в інших формах. Така прозорість і текучість меж у поезії М. Лаюка свідчить радше не про неминуче відчуття плинності, що іiі 3. Бауман [8] вважав визначальною ознакою світо- і самовідчуття сучасної людини, а про усвідомлення глибинної всепов'язаності світу, глобальної всеєдності, що відсилає не так до гуманітарних практик, як до сучасної фізики 3 iï концепцією голографічності Всесвіту. Лірика М. Лаюка демонструє читачеві мерехтіння форм, зміну оптики бачення, нюанси переходів, досі бачені хіба в поезії О. Лишеги і в прозі Т. Прохаська.

Усеохопність рослинної символіки (хоч Лаюкову лірику населяють ще й звірі, птахи, комахи і рептиліі) з усією очевидністю відсилає до мотиву метаморфози, потужно реалізованого в ліриці двотисячників (бо хоч Мирослав Лаюк - то вже наступне покоління десятників, не така вже й велика часова віддаль дозволяє говорити про певну спільність). Розмивання меж природного і людського, гібридизація людського тіла, що найчастіше реалізується через мотив метаморфози, не належить до специфічних рис поезії двотисячників, позаяк є успадкованою від міфології і фольклору потужною складовою літератури починаючи від найдавніших часів. Проте особливості втілення мотиву метаморфози, співвідношення природного / людського мають у ліриці двотисячників свою специфіку, що виявляється в актуалізації й фольклорного мотиву поглинання людського природним, i християнського протиставлення духовного / плотського (а отже, природного), й антоничевого всеохопного біологізму, й наявного в ліриці Плужника мотиву природи чужої, байдужої щодо людини. Так, природа як неприрученість особливо виразно постає в поезії К. Бабкіної та А. Малігон $[3,13-14 ; 3,171]$.

У цьому постлюдському світі поезії двотисячників вчуваються і постчорнобильска апокаліптика (як раніше - у ліриці В. Кордуна), й постання нетрагічної екологічної свідомості, що може без надриву і жаху помислити світ без людей (як у ліриці М. Григорова й М. Воробйова), і настанова на релятивність і вбогість тотальних істин людського світу, що розсіюються і зникають перед лицем Чужого (поезія М. Воробйова й В. Голобородька). Тому так легко тіло втрачає обриси людського, стає тілом тварини чи рослини в ліриці Катерини Бабкіної [3, 13], Тетяни Винник [3, 31], БогданаОлега Горобчука [3, 57], Олесі Мамчич [3, 178], Анни Малігон [3, 169-173]. Власне, міфологічний мотив метаморфози у ліриці двотисячників $\epsilon$ віддзеркаленням архаїчної тотожності тіла і космосу: так, космос мислиться 
влаштованим за моделлю людського тіла, себто йдеться саме про антропоморфізацію космосу, а не про космізацію людини [7, 313]. Мотив ковзання-переходу від людського до природного як метафори смерті, що має міфологічні корені, виразно вплетений у міфологічну модель циклічного часу 3 його неостаточністю смерті й переходом до життя в іншому тілі.

Та якщо в ліриці цих поетів наявні чисті й нетрансформовані міфологічні сенси, то в поезії Мирослава Лаюка рослинно-людське тіло причетне до творення дивовижних розламів і зсувів смислу, що своєю неочевидністю підважують прямолінійність мови. Тіло в його поезії втрачає тілесність питомо людську, делегуючи свою фізіологічність, свої функції й органи тілу рослинному: «у моєму саду росте дивна рослина / зелено-чорнолиста 3 червоно-синіми / стеблами-венами / вона зранку розцвітає білими головами» $[5,20]$, «червоний осоте / ти тут не той / ти / котрий має червоне волохате серце» [5, 113]. Рослинно-природне тут постає дзеркалом, в якому людина, що ii тілесність виявилася гранично непохопною, ненамацальною, намагається віднайти себе, але при цьому мислить себе як Іншого або й Чужого: «позбав мене імені осоте / я хочу стати тобою / я хочу хапати лисиць і козуль за лапи / і не полохати їх [...] я хочу стати собою / осоте» $[5,13]$.

У цій потребі віднайдення, збирання власної ідентичності, що розпадається на нетотожності, вчувається невтомне з'ясовування часопросторової протяжності себе як тіла: я є кимось іншим (просторові межі) і я $€$ щохвилини інакшим (часові межі). Більше того, природно-рослиннотваринне теж виявляється самовідчуженим (нетотожним собі) у процесі містеріального програвання культурних сюжетів, що через ініціацію надіндивідуальними смислами повертають цілісність фрагментованому Я: «вона може ніколи не цвісти / i ніколи не родити / але завжди 3 іiі тіла виростають голови / івана хрестителя / з червоними ротами» $[5,21]$, «а там качка-дичка - сіро-коричнева [...] вона прикована до гнізда своїм інстинктом / вона дивиться тобі в очі поглядом / богородиці / i тоді ти вибираєш міцну гілку / розмахуєшся / і лупиш нею з усієї сили по качці» $[5,35]$, «кажуть орфею / що ти звірів зачаровував співом / і зупиняв течію диких тракійських / струмків» [5, 42], «богоматір-лисиця / тримає у м'яких лапах руде богодитя» [5, 101]. Фрагментарність Я тут зумовлює ефект співпричетності - осягнення культурних смислів відбувається як повторне програвання ритуального сценарію, в якому Я присутнє як одночасність Саломеї та Іоанна; Орфеявбивці, Орфея-жертви, вбивці Орфея, мертвого звіра; янголів, Богоматері й Рафаеля тощо. Отже, Я в ліриці Мирослава Лаюка виявляється специфічним фрагментарно-гібридним конструктом: фрагментарним як роздрібненим, неусталеним у власній ідентичності й гібридним як фіто- i зооантропоморфним.

Мовою культурних сюжетів Лаюк переповідає (а радше втілює) нескінченно повторювану містерію кругообігу життя і смерті, що на рівні найближчих асоціацій відсилає до євангельського сюжету. Містерія розп’яття як безпосередня даність, закорінена в живу релігійну традицію, 
опосередковується власною осотовою міфологією Лаюка, а радше вплітається в Лаюкову міфологію як один із сюжетів: «сьогодні коли потемніє / я вирву твоє тіло осоте / з-під твоєї оливи в гетсиманському саду / і удосвіта розіпну» [5, 99]. Буття і смерть рослини як відбиття трагічного протиріччя між світом природи і світом культури лише засвідчує, що для Лаюка немає безпосередніх даностей, що в нього всі сюжети опосередковуються, а отже, сприймаються крізь призму рефлексії. Так, у вірші «кричи!» сюжет розп'яття контамінується 3 ніцшевським концептом смерті Бога й історією про Ніцше і кобилу, на побиття якої так гостро зреагував філософ: «кричи на вулицях богородице - / він все одно більше не вийде з храму / добивай господарю стару кобилу / їй вже все одно» [5, 48]. У концептуальному сенсі цей сюжет пов'язаний із пост- чи радше надгуманною етикою, що відмовляється від осмислення світу в координатах винятково людського сприйняття й розглядає світ як упорядковану i структуровану екосистему, в якій людина є важливою, але далеко не єдиною складовою. Те, до чого наближались у своїй творчості і маніфестах представники Київської школи (див. Кордунове твердження про людину як про рівновелику з іншими істотами частину світу [4] ), виявилось у творчості Мирослава Лаюка цілісною філософською концепцією, явленою в поетичному слові самодостатньо і потужно. Іще один нюанс полягає в тому, що євангельський сюжет розп'яття $є$ для поета не так смертю Бога, як смертю Сина, сприйнятою крізь призму свідомості Богоматері: «а на сутінках церкви вогні побілілі / виривають ісуса з рук діви марії» [5, 87]. Більше того, смерть Бога трансформується в самопожертву або й убивство Богородиці («тінь у річкових заростях» [5, 35-36], крім цього, ще й перегукується 3 віршем «Черепаха» Олега Лишеги, де немотивованість убивства розглядається саме 3 точки зору переосмислення дихотомії людське / звірине: невиправдана «звірина» жорстокість трактується як ознака саме людської поведінки, а звірине інтерпретується як підпорядковане, репресоване і загрожене Інше). 3 усією очевидністю в цих сюжетах відбивається досвід уважного прочитання текстів В. Герасим'юка 3 його специфічною інтерпретацією біблійних сюжетів з акцентом на жіночих постатях (див. поему «Єзавель») у контексті його власної міфології (Молода, дівчина). Інший приклад опосередкування релігійного сюжету культурним контекстом і одночасно - прочитання тексту природи крізь призму тексту культури, - це «рудий рафаель» $[5,101]$ iз його крилатими лисенятами і лисячою Богоматір'ю.

Своєрідним чином уписується в Лаюкову поетику і філософію орфічний міф («циганський театр - 7», «кажуть»), що входить як сюжет одночасно до кількох смислових блоків - містерії життя i смерті, містерії жертвоприношення (що в ньому у специфічний спосіб, як було розглянуто вище, актуалізується також євангельський сюжет розп'яття) i реалізується через концепцію надгуманної екологічної етики. Явлену в грецькому міфі перемогу діонісійського начала над аполлонівським, а отже - темного, звіриного, спонтанного, інтуїтивного над світлим, людським, раціональним, 
сконструйованим, що іï символізує розтерзаний вакханками Орфей, Лаюк розглядає крізь призму безпосереднього зіткнення природного і людського як співпричетність і відповідальність людини: «кажуть що музика яку ти озвучуєш - / шкодить / що вона викликає залежність / кажуть що ті котрі 3 різних причин / не змогли за тобою піти / помирали у муках» $[5,42]$. Проте, крім того, тут ідеться про концептуальну для Мирослава Лаюка матричність культури й культурних сюжетів, що мисляться чи не єдиним способом сприйняття й інтерпретації реальності. Хоч як це парадоксально, але природне (або те, що людина розуміє під природним) виявляється не полюсом дихотомії природне / культурне, а сферою, включеною в орбіту культурного. Тим самим на глибинному рівні актуалізується й важливе для поета християнське підгрунтя, адже йдеться про фундаментальну первинність замислу, плану творіння, ейдосу як про форму, що перетворює інертну матерію.

У збірці «Осоте!» актуалізовано базовий сюжет про померлого й воскреслого бога, варіантами якого $є$ і євангельська легенда про розп'яття й воскресіння, й почасти орфічний міф. Містерія жертвоприношення, що реалізується через такі варіанти, як легенда про Каїна і Авеля («солеварня»), Авраама та Ісаака («жертвоприношення»), Іоанна Хрестителя («рослина - 2 dance dance dance») й метаморфози осота (чи Осота?) $є$ доглибним переосмисленням не так сюжетів, як цінностей, що відбувається у площині зміщення співвідношень між світом природи, світом культури і світом окремої людини. Глобальна детермінованість життя окремо взятої людини визначається іiі підпорядкованістю як природному, так i культурному. Причому ця детермінованість культурою є всеохопною в бартівському сенсі: культура, що промовляє через людину, утримує іiі в силовому полі своїх смислів i кодів. Вельми показовим у цьому сенсі $\epsilon$ вірш «жертвоприношення»: культурний сюжет, пройшовши низку опосередкувань, стає матрицею, в якій втілена чуттєва реальність. Біблійна історія Авраама та Ісаака, опосередкована скульптурами геніального барокового різьбяра Іоанна Пінзеля, впосаджується не тільки в іншу естетичну систему, а й в етичну також, являючи собою універсальний символізм історії про мисливця і жертву, що повторюється не тільки в людському, а й у тваринному світі: «коли пави у клітях тремтітимуть / перед привидом лиса» $[5,15]$. Крізь історію чоловіка та його пса, якого той хоче «прив'язати до сухої верби і залишити / здихати», прозирає легенда про Каїна і Авеля - «ти не сторож свого собаки - бо навпаки / але чому в очах твоїх сіль?» [5, 26]. Таким чином актуалізується не тільки принцип матричності культурного тексту, що є специфічною формою сприйняття й інтерпретації реальності, а й фундаментальний етичний принцип, що поширюється як на людський, так i на позалюдський світ. Якщо поети Київської школи в другій половині 60-х утверджували «рівновеликість» людини і рослини (тварини), то Мирослав Лаюк як представник покоління 2000-х виходить із принципу екологічної етики, що передбачає докорінний 
перегляд символічних систем, зміну точки зору: віднині прерогатива творення смислів не належить виключно людині (так, у цитованому вище вірші пес виривається і кусає людину - тим самим підпорядковане вчиться не лише промовляти, а й виявляти свою суб'єктність).

Інший приклад детермінованості чуттєвої реальності культурними матрицями - вірш «бог вірджинія вульф». Міфологізація ландшафту відбувається як опосередкування життєвого факту культурним контекстом: трагічна історія хвороби і самогубства письменниці Вірджинії Вульф зміщується в іншу семантичну площину, стаючи міфом про річкового бога, що має «вовче прізвище» й «жіночу суть» [5, 93]. Річку Оуз, що в ній утопилась письменниця, теж прописано в двох площинах: у площині чуттєвої достеменності іï підводного світу й у площині міфу з його абстрактними безіменними ландшафтами («твоя річка тече з тебе / через твої підводні сади / до далеких пустель яких немає на мапах» [5, 93] ). 3 надзвичайною переконливістю поет демонструє, як конкретний історичний факт, позбуваючись побутової конкретики, в якій закорінено його унікальність i одиничність, переходить у вимір міфу 3 його універсальністю, повторюваністю і всеохопністю.

Циклічність i матричність міфу реалізуються також через особливі концепти, що лейтмотивом повторюються в кількох віршах збірки, будучи чимось на зразок бічних відгалужень центрального сюжету про муки, смерть і воскресіння Осоту. Таким чином певні смисли розгортаються не тільки лінійно, сюжетно в межах одного тексту, а й нелінійно - в межах збірки. Одним із таких концептів $є$ острів, що про нього згадано в поезіях «бог вірджинія вульф», «рослина - 2 dance dance dance», «циганський театр - 7» та деяких інших. Послідовно розгорнутий у збірці міфосюжет острова пов'язаний із містерією жертвоприношення - згадкою про відтяту голову Іоанна Хрестителя («рослина - 2 dance dance dance») і циганського Орфея («циганський театр - 7»). Така контекстуальність дає змогу потрактувати контамінацію античного і християнського міфів як глибинний символічний зв’язок між ними, здійснюваний у площині мистецтва. 3 огляду на це і спів Орфея, і танець Саломеї може бути інтерпретований як розгортання міфу про безсмертя, втілене в людських словах і жестах. Цей міф відбивається також i в символізмі рослинного світу, адже саме $з$ тіла дивної рослини на далекому острові виростають голови Іоанна Хрестителя.

Фундаментальність філософського запитування у збірці «Осоте!» полягає не в інтерпретації чинних смислів, а у спробі накреслити нові смислові координати. Глибоко проаналізований М. Толстим міфосюжет «житіє рослини» [6] в контексті поетики Лаюка втрачає сенс: якщо в традиційному міфі йдеться про постання культурного внаслідок жертвоприношення природного (народження хліба із зерна, полотна із стебла тощо), то новітній міф осоту оповідає про даремні муки і смерть бур'янини, що не вписується у світ окультуреної флори. Так сфера природного виявляється черговою самооманою, адже допустима вона постільки, поскільки не зазіхає на сферу 
людського. В глобальному сенсі йдеться про окреслення етики, що стосується Іншого, адже всі традиції, правила і заборони, що спонукають до дії, до перетворення світу й Іншого, виявляються лише символічними конструктами, що можуть бути легко змінені, хоч і здаються непорушними. Лаюк ілюструє це, окреслюючи свій Осот як універсальну символічну фігуру, придатну до наповнення будь-яким змістом, протеїчну форму, в яку легко вкладаються Я, Бог, Диявол, Інший і Чужий. Осот виявляється одночасно симулякром і осердям істини («саме тим»), рослиною і текстом, пойменованим i безіменним: саме пошук імені й символічне його віднайдення (на це натякає форма кличного відмінка в назві збірки) виокремлюють Іншого як інакшого свого, а не далекого-чужого-ворога.

Наріжна опозиція природного / культурного потрібна поетові для ревізії досі непорушних смислів і співвідношень, на яких тримався культурний консенсус. Прийняття Іншого в його інакшості відбувається як екологічна містерія, що скасовує ієрархічні стосунки влади і підпорядкованості на користь паритетності й діалогу: саме тому всі значущі культурні сюжети програються в декораціях природного (реального, чуттєвого) світу. Культурний текст осмислюється як матриця сприйняття й інтерпретації чуттєвої реальності, й саме як такий він не $\epsilon$ непорушним і може утворювати різні конфігурації відповідно до різних правил.

\section{ЛIТЕРАТУРА}

1. Гейзінга Й. Homo Ludens: Пер. $з$ англ. / Йоган Гейзінга. - К.: Основи, 1994. $-250 \mathrm{c}$.

2. Герасим’юк В. «Позбав мене імені...» / Василь Герасим’юк // Лаюк М. Осоте!: Поетична книжка. - К.: Смолоскип, 2013. - С. 211-222.

3. Дві тонни: Антологія поезії двотисячників. Упоряд. Б.-О. Горобчук, О. Романенко. - К., 2007.

4. Кордун В. Київська школа поезії - що це таке? / Віктор Кордун // Світовид. - 1997. - № 1-2 (26-27). - С. 7-20.

5. Лаюк М. Осоте!: Поетична книжка / Мирослав Лаюк. - К.: Смолоскип, 2013.

6. Толстой Н. И. Vita herbae et vita rei в славянской народной традиции / Н.И. Толстой // Славянский и балканский фольклор: Верования. Текст. Ритуал / Отв. ред. Н. И. Толстой. - М.: Наука, 1994. - С. 139-168.

7. Трубачев О. Н. Славянская этимология и праславянская народная культура / О.Н. Трубачев // X Международный съезд славистов (София, сентябрь 1988). Славянское языкознание. Доклады советской делегации. Отв. ред. акад. Толстой Н.И. - М.: Наука, 1988. - С. 292-347.

8. Bauman Z. Liquid Modernity. - Cambridge: Polity Press, 2004.

Статья посвящена поэтике сборника «Осоте!» Мирослава Лаюка. Оппозиция природного / культурного осмысливается как основание для ревизии культурных смыслов и отношений, на коих базировался культурный 
консенсус. Согласно этому, культурный текст может быть интерпретирован как матрицуа восприятия чувственной реальности.

Ключевые слова: Мирослав Лаюк, оппозиция природное / культурное, свое / иное, экологическая мистерия.

The article is focused on the poetic aspect of "Thistles!" story collection by Myroslav Layuk. Natural and cultural oppositions are conceptualized as a basis for the revision of cultural meanings and relationships that are based on cultural consensus. It's proven that cultural scenes are seen and recognized by M. Layuk in dynamics of natural processes and phenomena; rather, cultural optics dominate in other ways of seeing and reflecting. Using the language of cultural plots Layuk retells (but rather embodies) the mystery of the never-ending cycle of life and death. The perception of The Alternative goes as the course of an ecological mystery, that abolishes the relationship of hierarchical authority and subordination in favor of parity and dialogue. Basically, the cultural text can be interpreted as a matrix of sensory perception of reality.

Keywords: Myroslav Layuk, opposition natural / cultural, his / The Another ecological mystery. 